\title{
The experience of patient suicide among Irish psychiatrists
}

\author{
Elizabeth M. J. Cryan, Paul Kelly and Brian McCaffrey
}

\begin{abstract}
One hundred and nine consultant poychictitsts completed on anonymous questionnatre on the suicide of potients in theitr care. A patient sulelde wos reported by $82 \%$, of whom $47 \%$ had exporienced their first patient sulcids within five years of entering poychiatilic practice. A formal roviow of the suiclde had oceured in $24 \%$ of coses. The study oxamines the percelved eflocts of thelr first potient sulcide on the protesional proctice of the respondents, and mecisures the personal stress related to $I I$, using the impact of Event Scole. We discuss the implicotions of this common experience for poychiaticic training programmos.
\end{abstract}

The suicide of a patient can have a traumatic effect on relattves and cliniclans alike. In addition to loss, there frequently follows a period of prolonged questioning-a search for meaning. Families feel stigmatised by suicide, and may be unwilling to discuss it, a position compounded by social attitudes of blame (Ness \& Pfeffer, 1990). Psychiatrists share some of these experiences when their patient commits suicide (Litman, 1965). They may experience anger and sadness, with consequent blame, guilt and denial, associated with obsesstve reviewing and impaired performance. Fears of blame or legal action may lead to avoidance of contact with the family and of the funeral. Selfdoubt regarding clinical performance may result in conservatism or avoldance of suicidal patients.

The reported frequency of patient suicide as experienced by psychiatrists varies from 2257\% (Kahne, 1968; O'Reilly et al, 1990). However, the available studies have been done in North America and may not reflect the experience of Irish and British psychiatrists.

The aims of this study were:

(a) to ascertain the proportion of Irish psychiatrists who have experienced the suicide of one or more of their patients

(b) to determine the frequency of formal reviews and funeral attendance following patient suicide

(c) to estimate the level of stress following the first patient suicide (immediately and currently), using the Impact of Event Scale (Horowitz et al, 1979), and

(d) to estimate the effect of the first patient suicide on respondents' clinical practice.

\section{The study}

An anonymous questionnaire was sent to 178 psychiatrists working in Ireland with a reminder two months later. This included questions on gender, years in practice, type and location of practice and therapeutic orientation, in addition to experience of patient suicide during treatment. In the event of a patient suicide having occurred, the respondents completed questions regarding their years in psychiatric practice at the time of their first suicide, whether the patient was an in-patient, and whether there was a formal review following the event. They indicated how they felt the first patient suicide had affected their practice of psychiatry on a four point scale (from no impact to major impact) in the areas of likelihood to admit patients to hospital, record-keeping, legal aspects of practice, use of peer consultation and focus on suicide. They recorded whether they had attended the funeral and if so whether this had been helpful personally and to the patient's relatives. They then completed the Impact of Event Scale (Horowitz et al, 1979) for the two weeks following the first patient suicide, and for the two weeks prior to completing the survey. This scale is a 15-item, self-report, forced choice questionnaire which measures subjective stress related to a specific event. It divides into two sub-scales which measure intrustve thoughts and dreams related to the event and avoldance responses. 


\section{Findings}

The sample

One hundred and nine psychiatrists completed the survey (61.2\%). A wide range of subspeciality interests and therapeutic orientations was represented, and the mean duration of psychiatric practice of the respondents was 18.7 years.

\section{The experience of patient suicide}

Eighty-two per cent reported that a patient had committed suicide during treatment, and of those reporting one suicide, $81 \%$ had experienced more than one. The first suicide occurred within five years of starting psychiatry for $47 \%$, and while the patient was an in-patient for 31\%. A formal review followed the event for 24\%. Fifteen per cent attended the funeral, of whom 55\% found it personally helpful, and $62 \%$ considered it helpful to the patient's relattves. There was no difference in gender or years of psychitatric practice between those who had experienced patient suicide and those who had not. Eightyeight per cent of general adult psychiatrists, compared with $50 \%$ of child and adolescent psychiatrists and $57 \%$ of mental handicap psychiatrists, reported a patient suicide.
Effects of patient suicide on professional practice

The percentage of psychiatrists who reported that their first patient suictde had brought a definite or major impact on their likelihood to admit patients to hospital was $15 \%$, on detailed record keeping, 31\%; on increased use of peer consultation, 25\%; on increased attention to the legal aspects of practice, $25 \%$; and on increased focus on suicide, $58 \%$.

\section{Personal stress of first patient suicide}

Table 1 shows the Impact of Event score divided into the sub-scales of intrusion and avoldance for the two weeks following the first patient suicide and currently. Scores on the intrusion sub-scale of greater than 12 and on the avoidance sub-scale of greater than 10 were considered significant, as they were within one standard deviation of the reported mean scores for a clinically bereaved group seeking treatment following the death of a parent. Using these cut-off points, 'clinical' intrusion was experienced by 31 (36\%) respondents, and 'clinical' avoidance by 15 (17.5\%) inittally. This compared with 4 (5\%) and $6(7 \%)$ respectively in the two weeks prior to filling out the survey form.

Table 1. Impact of event scores for first patient suicide

\begin{tabular}{|c|c|c|c|c|c|c|}
\hline & \multicolumn{3}{|c|}{ Two weeks following sulcide } & \multicolumn{3}{|c|}{ Two weeks prior to completing the surven } \\
\hline & Number & $\begin{array}{l}\text { Moon } \\
\text { Intruston } \\
\text { (se) }\end{array}$ & $\begin{array}{l}\text { Mean } \\
\text { ovoldance } \\
\text { (sd) }\end{array}$ & Number & $\begin{array}{l}\text { Mecn } \\
\text { Intrusion } \\
\text { (ed) }\end{array}$ & $\begin{array}{l}\text { Mean } \\
\text { avoldanco } \\
\text { (ed) }\end{array}$ \\
\hline $\begin{array}{l}\text { Total } \\
\text { Gender }\end{array}$ & 86 & $10.8(6.4)$ & $5.8(7.2)$ & 84 & $2.0(4.4)$ & $0.9(2.1)$ \\
\hline $\begin{array}{l}\text { Male } \\
\text { Female } \\
\text { Setting }\end{array}$ & $\begin{array}{l}45 \\
33\end{array}$ & $\begin{array}{r}9.7(7.1) \\
12.2(6.8)\end{array}$ & $\begin{array}{l}5.5(6.5) \\
5.8(6.3)\end{array}$ & $\begin{array}{l}43 \\
33\end{array}$ & $\begin{array}{l}2.2(4.4) \\
1.8(4.7)\end{array}$ & $\begin{array}{l}1.1(2.4) \\
0.5(1.3)\end{array}$ \\
\hline $\begin{array}{l}\text { Uiban } \\
\text { Rural } \\
\text { Locotion of suiclde }\end{array}$ & $\begin{array}{l}53 \\
21\end{array}$ & $\begin{array}{l}11.4(7.7)^{*} \\
7.8(4.9)\end{array}$ & $\begin{array}{l}5.5(5.8) \\
5.6(7.4)\end{array}$ & $\begin{array}{l}50 \\
23\end{array}$ & $\begin{array}{l}1.5(3.0) \\
0.9(2.2)\end{array}$ & $\begin{array}{l}0.6(1.4) \\
0.7(2.0)\end{array}$ \\
\hline $\begin{array}{l}\text { Hospltal } \\
\text { Out-patlent } \\
\text { Years of practice }\end{array}$ & $\begin{array}{l}27 \\
58\end{array}$ & $\begin{array}{l}10.7(8.5) \\
10.9(6.6)\end{array}$ & $\begin{array}{l}5.6(7.5) \\
5.7(5.7)\end{array}$ & $\begin{array}{l}24 \\
59\end{array}$ & $\begin{array}{l}2.5(6.6) \\
1.8(3.8)\end{array}$ & $\begin{array}{l}1.0(2.2) \\
0.8(2.1)\end{array}$ \\
\hline $\begin{array}{l}\text { Less than } 5 \\
\text { Greater than } 5 \\
\text { Formal reviow }\end{array}$ & $\begin{array}{l}40 \\
46\end{array}$ & $\begin{array}{l}11.8(8.5) \\
10.0(5.9)\end{array}$ & $\begin{array}{l}6.1(6.3) \\
5.6(6.5)\end{array}$ & $\begin{array}{l}41 \\
43\end{array}$ & $\begin{array}{l}2.0(4.9) \\
2.0(3.9)\end{array}$ & $\begin{array}{l}0.6(1.5) \\
1.1(2.6)\end{array}$ \\
\hline $\begin{array}{l}\text { of sulctole } \\
\text { Present } \\
\text { Absent }\end{array}$ & $\begin{array}{l}20 \\
64\end{array}$ & $\begin{array}{r}8.9(6.0) \\
11.5(7.6)\end{array}$ & $\begin{array}{l}6.3(7.4) \\
5.5(5.9)\end{array}$ & $\begin{array}{l}19 \\
63\end{array}$ & $\begin{array}{l}1.4(2.5) \\
2.2(4.8)\end{array}$ & $\begin{array}{l}0.6(1.4) \\
0.9(2.4)\end{array}$ \\
\hline
\end{tabular}

$-P<0.05$ 


\section{Comment}

The $82 \%$ of Irish consultant psychiatrists who have had a patient commit suicide is higher than reported from studies in North America, where the highest figure was 57\% (O'Reilly et al, 1990). The difference could be accounted for by a higher known to unknown ratio of suicides in Irish practice, since the population is small and less mobile. Henn (1978) found that the known to unknown ratlo among psychiatric residents in Los Angeles for patient suicide was $1: 12$, but this related to contact within the previous year, and not to current treatment. It might also be accounted for by differences in the structure of psychiatric services between Ireland and North America, with the latter including a larger proportion of psychiatrists working in private psychotherapeutic practice, with less severely ill patients.

Brown (1987a\&b) has highlighted the particular difficulties for psychiatric trainees when a patient in their care commits suicide. Although protected to some extent by the 'training umbrella', their personal sense of failure may be greater because of lack of expertise, and the sudden confrontation with their limitations in achieving "deeply held narcissistic aspirations". In this study, 47\% of respondents who had experienced patient suicide did so during training, but their initlal scores on the Impact of Event Scale were not significantly higher than those for whom patient suicide occurred later in clinical practice. Chemtob et al (1988) did find that younger, less experienced clinicians were more affected by a patient's suicide, and in their discussion, emphasise the need for establishing formal mechanisms to deal with Its impact. A formal review followed the patient suicide for only $24 \%$ of the respondents in our study, but there was no significant difference in their Impact of Event scores compared to those who did not have such a review. However, this could be related to the particular circumstances surrounding the suicides where a review occured, or to the small numbers (20 and 64 respectively) which may have been insufficient to detect a difference.

The personal stress related to their patient's suicide, as measured by the Impact of Event Scale, while significant, was lower than that recorded by American psychiatrists (Chemtob et al, 1988), where $53 \%$ of the sample had initial scores comparable to a clinical group. In our study, clinical levels of intrusion were reported by $36 \%$ and avoldance by $17.5 \%$. However, only $15 \%$ attended their patient's funeral, and this, in a culture where funeral attendance is the accepted norm in everyday life, might indicate a higher level of avoldance than reported. The differences between the American and Irish psychiatrists may be cultural, or may relate to the more widespread practice of psychoanalysis in America, with the formation of long-term intense transference and countertransference relationships, resulting in a greater sense of loss and fallure with suicide.

Apart from 'focus on suicide', the majority of respondents did not report that patient suicide had brought a definite or major impact on their professional practice. However, $15 \%$ did consider themselves more likely to admit patients to hospital - a change in practice with serious consequences in the context of reducing in-patient bed numbers.

Brown (1987a\&b) has suggested that training schemes introduce a "comprehenstve programmatic response" to patient suicide. This should include an anticipatory phase, in which trainees, in addition to learning about the epidemiology and dynamics of suicide, are encouraged to imagine their own reaction in the event of a patient committing suicide. He also suggests the introduction of policies of joint care with a senior psychiatrist for extremely suicidal patients, while ensuring clear clinical responsibility. When suicide occurs, the trainee should be initially offered support and an opportunity to ventllate his or her feelings with a senior colleague, and also supported in meeting the patient's relatives. After a period of some weeks, the "psychological autopsy" should allow an opportunity to examine the possible reasons for the suicide, to evaluate the quality of the care given, and the effects on the patient's family and therapist. Brown also suggests two follow-up phases, the first to assess the individual trainee's progress with resolution. and the second to prepare trainees for independent clinical practice. We could usefully implement these recommendations, given that patient suicide is an almost universal event for Irish (and most likely British) psychiatrists, frequently occurs during training, and has significant personal and professional consequences. The programme could also be usefully extended to other mental health professionals in the context of evolving community services. 


\section{Aclonowledgements}

The authors would like to thank the Eastern Health Board, Special Hospital Care Programme, who funded the project, and Ms Jean Gavin.

\section{References}

BROWN, H. R. (1987a) The impact of sulcide on theraplsts in training. Comprehenstue Psychiatry, 28, 101-112.

-(1987b) Patlent sulcide during reaidency training: incidence, implications and programme response. Joumal of Psychtatric Education, 11, 201-216.

ChrantoB, C. M., HAMADA, R. S., BAUER, G., KInNeY, B. \& TORIGOE, R. Y. (1988) Patients suicldes: frequency and impact on peychilatrists. American Joumal of Psychlatry. 146, 224-228.

HENN, R. F. (1978) Patient sulcide as part of poychlatric residency. American Joumal of Psychlatry. 138. 745746.

HOROWITZ, M., WLNER, N. \& ALVAREZ, W. (1979) Impact of Event Scale: a measure of subjective stress. Psychosomatic Medictine, 41, 209-218.
KAHNE, M. J. (1968) Sulclde among patients in mental hoopitals. A study of the poychlatrists who conducted their poychotherapy. Psychiatry. 3, 32-43.

LTMNN, R E. (1965) When patients commit sulcide. American Joumal of Psychotherapy. 4. 570-576.

NESS, D. E. \& PFErTER, C. R. (1990) Sequelae of bereavement resulting from sulcide. American Joumal of Psychlatry, 147, 279-285.

O'RenLY, R. L., TRUANT, G. S. \& DONALDSON, L. (1990) Psychlatrists' experience of suicide in their patients. Psychiatric Journal of the Universtty of Ottawa, 18, 173176.

Elizabeth M. J. Cryan, Consultant Psychiatrist, James Connolly Memorial Hospital, Blanchardstown, Co Dublin and Honorary Lecturer in Clinical Psychiatry, Royal College of Surgeons in Ireland; Paul Kelly, Tutor in Psychology, Untwerstty College, Dublin; and Brian McCaffrey, Consultant Psychiatrist, St Vincent's Hospital, Fairvtew, Dublin 3, Republic of Ireland

\title{
The emergency treatment of overdose: a problem of consent to treatment
}

\author{
Tim Hardie, Kamaldeep Bhui and Phillip Brown
}

We auvoyed 119 poychichtists to see how thoy would act with a patient who has taken a potentially lothal overdose, has no mental illness, and ts refueing treatment. There wos aubetantiled discoreement. There moy bo a risk of action under clvill low whether the poychictitis decides to treet the potient without his or her consent or not. The Low Commiseton are examining whether mental disorder, as defined in the Mental Heath Act 1983, should be used as a test of incopoclty to give consent to modiced treatiment. such lectalation would help doctors but moy encourage a wide interprefation of the definition of mental disorder.

Psychiatrists may be called to assess patients who are refusing treatment following an overdose. If the patient is not amenable to persuasion, the psychiatrist may be asked to decide whether treatment should be given without the patient's consent. If treatment is forctbly administered, then the doctor may expose himself to a suit for trespass, assault or battery. If the doctor chooses not to treat the patient, and the patient suffers as a result, he may be sued for negligence. The main defence in the former case will be that of 'necessity' and in the latter case it will be that of volenti non fit injuria', ie. that the patient voluntarlly assumed the risk of not giving consent for treatment (Korgaonkar \& Tribe, 1993). In a case of alleged negligence, breach of duty of care will be judged on the "expert opinion of medical witnesses giving their views on current modes of accepted practice" (NelsonJones \& Burton, 1990)

Although current practice regarding consent to medical treatment is governed by common law, the Law Commission are examining whether a test of incapacity to consent to 